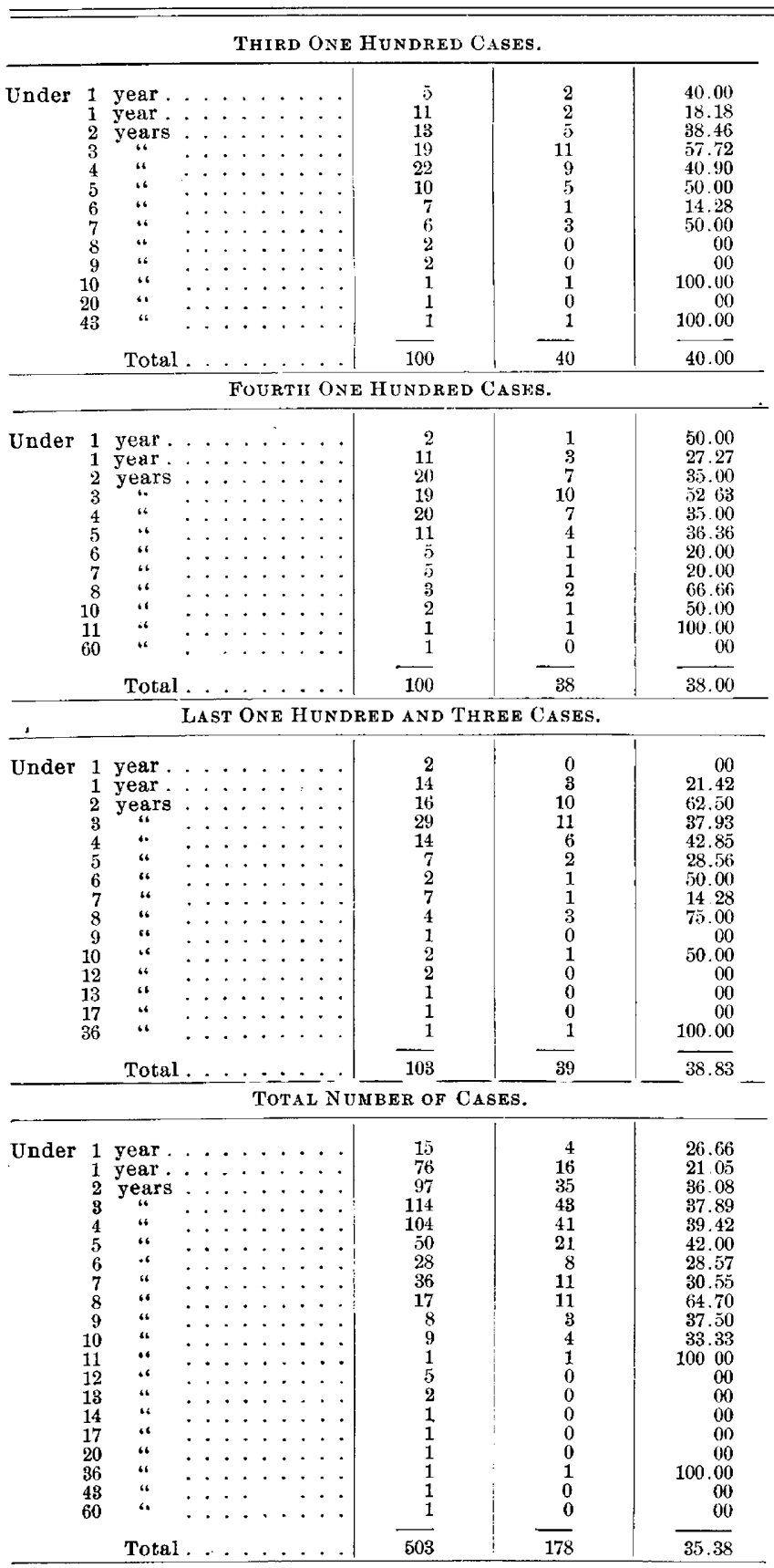

I can not close this paper without emphasizing the importance of the use of antitoxin in cases of laryngeal diphtheria. I am fully convinced that antitoxin limits the extension of diphtheritic exudation as does no other remedy that we possess and as the danger lies chiefly in the extension of this membrane it is apparent that the remedy should be employed early before the membrane has extended to the lower trachea and to the bronchial tubes. In a case of diphtheria, the very moment that it is evident from the slightly embarrassed respiration and croupy cough, that the larynx has become invaded the remedy should be used. By the early use of antitoxin in these cases not only will many operations be avoided but many cases requiring operation will be saved that would otherwise perish. In corroboration of this statement I would say that since the general use of this remedy in Denver I have been called much less frequently by my confrères to operate than formerly, and in those cases operated upon a much larger percentage have been saved.

\section{THE EMINENTLY SCIENTIFIC NATURE OF OUR PATENT AND COPY- RIGHT LAWS.}

\section{THE KLEBS ANTIPHTHISIN CASE.}

\section{BY F. E. STEWART, M.D., PH.G.}

DETROIT, MICH.

For the purpose of promoting progress in science and the useful arts the Constitution of the United States gives Congress the power to grant to authors and inventors for limited times the exclusive use of their respective writings and discoveries. On the clause in the Constitution referred to, our patent and copyright laws are based. The question at issue is the right to copy. The copy right law refers to the right to copy the writings of others; while the patent laws refer to the right to copy the inventions of others. Now I propose to show that it is just as equitable for the medical profession to endorse the patent as applied to medicine, as it is to endorse the copyright as applied to literature. At the same time I hope to make it clear that so-called "Patent" medicine business is a misnomer; and I hope to show that what is generally known as the "Proprietary" medicine business possesses no property in medicines whatever, and is a misnomer likewise.

All will admit that the promotion of science and the useful arts is of great benefit to society at large, and any fair minded man will agree that capital invested in business should be properly protected. If, therefore, there is a law which will protect both science and commerce at the same time such a law must be truly beneficent. Such exists in our patent law, which, if properly applied is capable of effecting that most desirable end.

" A patent is a contract between the inventor and the government representing the public at large. The consideration moving from the inventor is the production of a new and useful thing, and the giving to the public a full knowledge thereof by means of a proper application for a patent, whereby the public is enabled to practice the invention when the patent expires. The consideration moving from the government is the grant of an exclusive right for a limited time, and this grant the government protects and enforces through its courts." Simond's Manual of Patent Law, p. 11.

The patent office at Washington is a great bureau of archives representing progress in science and the arts in the United States. Any one who wishes to post himself in regard to inventions in any special line of work can obtain full knowledge of everything patented in that line by applying at the patent office. Models, drawings, descriptions, working formulas, are all there for inspection; and he can secure, at small cost, copies if he so desire.

Many useful arts of the ancients have been lost to the world for lack of publication which would have been preserved if patent laws similar to those devised by our law makers had been in force. The necessity of securing the publication of the art of manufacture of every medicine must be apparent to every one. In case of a patented medicine such publication is secured. Moreover, the inventor, to whom the world is indebted for the discovery of a new and useful thing receives well merited reward for his labor.

The patent law provides "That any person who has invented or discovered any new and useful art, 
machine, manufacture, or composition of matter, or any new and useful improvement thereof, not known or used by others in this country, and not patented or described in any printed publication in this or any foreign country, before his invention or discovery thereof, and not in public use or on sale for more than two years prior to his application, unless the same is proved to have been abandoned, may upon payment of the duty required by law, and other due proceedings had, obtain a patent therefor." Sect. 24 , Act of July 8, 1870.

It may be observed, first, that an invention for which a patent is sought must be original with the applicant; second, it must be new and useful; third, full knowledge of it must be filed at the patent office; fourth, the grant is limited to a term of years at the end of which the monoply ceases, and the invention becomes common property.

If all these requirements are not complied with the patent is invalid, even if granted, and the courts owe it to the public not to protect inventions when the demands of the patent law are ignored. Now I contend that the enforcement of these demands, when patents for medicines are applied for, would do much to correct the abuses which are throwing our laws into disrepute in their relation to medicinal preparations.

The inventions specified as patentable are:

1. Au art or an improvement of an art.

2. A machine or an improvement of a machine.

3. A manufacture or an improvement of a manufacture.

4. A composition of matter or an improvement thereof.

To define what constitutes a new art, machine or manufacture, or an improvement thereof is sometimes a difficult task. But it is far more difficult for courts to define what constitutes new and useful compositions of matter or compositions thereof. The law requires that an invention to be patentable, must be "new and useful." To define what are new and use. ful compositions of matter may require the most profound knowledge of chemistry; and when referred to therapeutic inventions, a score of expert physicians and chemists might be required to settle it. Yet patents have been granted without any attempt being made worthy of the name to ascertain whether the alleged inventions conformed to the demands of the patent law or not. More care should be taken to carry out the wise provisions of the Constitution in this connection, so that the patent law shall promote and not hinder progress in the science of therapy and pharmacy. Surely no patents should be granted for medical compounds unless the applications are first submitted to a commission of physicians and chemists to pass thereon; and the courts should not attempt to decide questions of infringement without first consulting such a commission.

Another point of great importance in the application of patent law to medicine is the question of naming new compositions of matter. Mistaking the nature of the patent privilege some inventors have registered the names of their inventions as trademarks for the purpose of continuing the monopoly after the patents expire, and thereby defeating the patent law. Now it is cerainly true that if the only name by which a compound is known may be legally used as a trade mark, it is equally true that its use as a trade mark may be continued indefinitely after the patent has expired, so that the trade mark law may render the patent law ineffective so far as pro. moting progress in science and the arts is concerned. But when the patent expires the article according to the contract between the inventor and the government, becomes common property. Surely. under the contract, it is not fair to permit the inventor to exercise a perpetual control over the name of the article and thus exclude the public from an equal chance in its manufacture and sale. Moreover, the name by use becomes descriptive of the article, and it is an axiom of law that a descriptive name can not be made a trade mark

Mr. George H. Lothrop of Detroit, one of the most eminent patent lawyers in America, in a conversation recently used an illustration which seems to make clear the absurdity of claiming the only name of an article as a trade mark. He said: "When a baby is born into the world, a name is given it. Does the name of the baby belong to the baby or to the one who gave the baby its name?" Every new thing born into the world must have a name; and that name belongs to the thing, not to the one who named it. While the patent is in force the use of the name is restricted to the patentee along with the invention, but when the patent expires both should, and I hold that they do, become common property.

Now, as we have no law in this country granting the exclusive use of articles of trade to individuals except the patent law, and as every article not patented in which the world is trading is free to the public to manufacture and sell, it follows that there is no property in a medicine unless it is patented. The majority of medicinal compounds on the market are not patented. The reasons for this are various. First, only a few of them are patentable, being mere aggregations of old and well-known drugs. Next, the manufacturers had rather rely on secrecy and semisecrecy for protection than expose their trade secrets by an application for a patent. Then the monopoly permitted by the patent law is limited, and it is possible to monopolize a medicinal compound indefinitely by secrecy as to its true or working formula. But it is hardly a correct definition to call these unpatented compounds proprietary medicines, for it inculcates the idea that there is property in them (which there is not), and that any one except the introducer who may desire to manufacture and sell them is guilty of piracy. As well might every manufacturer of pens, ink, paper, silk and woolen goods, and of every article of commerce not patented be called a pirate. Competition is the life of trade, and it is this mistaken idea that every manufacturer of unpatented articles except the introducers are pirates, imitators and infringers of the rights of others that is throttling the entire manufacturing interests of the United States as far as medicine is concerned.

If the medical profession and the pharmacists of this country would combine on this one thing and demand that every medicinal composition shall be published and provided with a name under which it may be manufactured and sold by all, it would do more than anything else to blot out that great misnomer, the so-called "patent medicine" business. It is a wise and just policy that rewards the inventor of a new and useful composition of matter with a patent. But let no patents be granted for medicines unless there are reasonable grounds for believing that they are new and useful inventions, and then see to it that the scientific and beneficent ends of the patent law 
are carried into practice. The protection of labels' trade marks and packages is indispensable to the existence of trade and a great protection to the public, but let it be known that there is no legal warrant in the use of the only name of an article as a trade mark. Such a use of it creates a perpetual monopoly, protects secrecy, kills all competition and is an open door to fraud.

Another very important point in this connection is the right possessed by the government representing the public at large to refuse a patent to an inventor when public policy demands it. The granting of a patent that will hinder progress in science and useful arts is contrary to the policy of the patent law. "The policy of the patent law is, primarily, a selfish one on the part of the public, and only second. arily intended for the benefit of inventors, and then as a means to an end only." Simond's Manual. The same author states that the United States Supreme Court has, twice at least, decided that a principle can not be patented, "and this in one instance when one of the most important of all inventions of all ages was under consideration-that of the electric telegraph." The Government thought that by giving the inventor a monopoly it would delay the development of that most useful discovery, and so refused the application. In the same manner the gorermment has a right to refuse a patent upon a chemical, such as phenricetin, for example. A patent on a process or machinery for making the chemical might not be objectionable, but the granting of a patent upon the chemical itself, and thus cutting off all opportunity for developing new and improved methods for its production does not seem wise public policy and compatible with the end in view, viz., the promotion of progress in science and the arts. Especially does the policy seem a foolish one when the manufacture of the chemical is conducted in Germany, and results in the enrichment of a foreign corporation. Still more foolish does it seem when it is considered that Germany will grant no such privileges to American inventors manufacturing in this country and exporting to Germany. But the height of unfairness is reached when our laws are so construed that phencectin is protected in this country so that it costs at wholesale $\$ 16$ a pound, when, according to the Chemist and Druggist, it can be purchased under its chemical name (paraacetphenetidin) in England for about $\$ 1.25$ per pound.

Now for the practical application of all this to the "Antiphthisin" case. Dr. C. P. Ambler, Associate Medical Director and Laryngologist, Winyah Sanitarium, Ashville, N. C., an institution where that preparation is being exploited, asked the privilege of reading a paper on the subject of "Antiphthisin" before the Section on Materia Medica, Pharmacy and Therapeutics of the American MEdical Association. As chairman of the Section I gave my consent. This I was justified in doing, as "Antiphthisin" is the invention of the famous scientist, Klebs, of KlebsLöffler bacillus fame, and Prof. Klebs was present in person to discuss the subject. In the discussion it developed that the product known as "Antiphthisin" is patented in Germany and a patent applied for it in this country. The name "Antiphthisin" is also registered as a trade mark in the Patent Office at Washington. "Antiphthisin" will not be made in this country, but will bear a stamp "Made in Germany." As the Code of Ethics of the AmErican MEDICAL
Association forbids physicians prescribing patented medicines it is not surprising that there were mem. bers present who seriously objected to permitting Dr. Ambler's paper to go unchallenged. Accordingly a resolution was passed and referred to the Business Committee of the Association in condemnation of "Antiphthisin." The Business Committee is com. posed of conservative gentlemen who will doubtless decide the question on its merits, yet it would be a very unfair thing to affix any serious penalty on Dr. Ambler for reading his paper, or to take any action under the circumstances that might injure the good name and reputation of Dr. Klebs.

When it is considered that probably 25 per cent. of the medicines prescribed by the members of the American Medrcal Association are claimed as proprietary by their manufacturers is it any wonder that Dr. Klebs considered the rule against proprietary medicines of no binding force, even if he knew of its existence? Was it any more objectionable for Dr. Ambler to read a paper before the Section on "Antiphthisin" than it would have been if he had made the subject "The Comparative Merits of Phencrcetin, Antipyrin and Salol"? All these substances are patented, and their names are registered as trade marks.

Now is the time for the Ariericar Medical AssociATION to take definite action in relation to the subject of patented medicines. Something must be done The Association will not be satisfied with any compromise measures. The patenting of medicines is right or it is wrong. Personally I believe it is right if the scientific demands of the patent law are complied with. Now that the matter is brought clearly before the Association by the Klebs case let the mat. ter be carefully considered, and acted on in a manner fair to all concerned. If the Code is to be sustained in this instance then let it be enforced all along the line and dismiss every member of the Assocration who prescribes phenacetin, antipyrin and salol. The Code can not be enforced in this matter. What then shall we do? Shall we indorse the use of patented medicines without qualification, and thereby indorse the nostrum trade in toto, to the utter ruin of scientific pharmacy? Shall we repudiate those manufacturing houses who have sacrificed many opportunities of making money by standing by the profession and throw our influence in favor of those who leave no stone unturned to throw the profession into disrepute by advertising to cure incurable diseases and jeering at the medical profession because of its admitted impotence in such cases? These are serious questions that demand an answer and the nostrum trade will not be slow to seize the opportunity to use it for the advancement of the nostrum business unless we answer these questions in such a manner that it will leave no doubt in the minds of the public in regard to our true position. We can not afford to fight the patent law, founded as it is on the Constitution of the United States, as it is eminently scientific and just, but we can demand that it shall be so enforced as to promote progress in the science of medicine and the useful arts of pharmacy and therapy, and not be a hinderance to all progress by patenting principles, protecting secrecy, killing competition and throttling trade under the guise of law.

Ichthyol ip Orchitis.-Dr. Leedom Sharp recommends enveloping the inflamed testicle and cord in a 30 per cent. ichthyol ointment.-Univ. Med. Mag., August. 